\title{
PENGARUH METODE PEMBELAJARAN WHOLE BRAIN TEACHING TERHADAP HASIL BELAJAR IPA SISWA KELAS VIII SMP NEGERI 18 PALU
}

\author{
Isnawati, Yusuf kendek dan Syamsu \\ wisna31@yahoo.co.id \\ Program Studi Pendidikan Fisika FKIP Universitas Tadulako \\ Jl. Soekarno Hatta Km. 9 Kampus Bumi Tadulako Tondo Palu - Sulawesi Tengah
}

\begin{abstract}
Penelitian ini bertujuan untuk melihat ada tidaknya pengaruh metode pembelajaran Whole Brain Teaching terhadap hasil belajar IPA siswa kelas VIII SMP Negeri 18 Palu. Jenis penelitian yang digunakan yaitu eksperimen kuasi dengan desain "The Equivalen Pretest-Posttest Design". Sampel dipilih dengan menggunakan teknik random sampling. Sampel penelitian yaitu kelas $\mathrm{VIII}_{\mathrm{A}}$ sebagai kelas kontrol dan kelas $\mathrm{VIII}_{B}$ sebagai kelas eksperimen. Instrumen yang digunakan berupa tes hasil belajar dalam bentuk pilihan ganda. Berdasarkan hasil pengolahan data, untuk kelas eksperimen diperoleh rerata skor tes awal adalah 6,53 dan untuk tes akhir adalah 13,26 dari skor ideal yaitu sebesar 20. Untuk kelas kontrol diperoleh rerata skor tes awal 6,16 dan untuk tes akhir adalah 9,26 dari skor ideal yaitu sebesar 20. Berdasarkan hasil pengujian N-Gain kedua kelas masing-masing berada dalam kategori berbeda yaitu kelas eksperimen berada dalam kategori sedang dengan nilai N-Gain sebesar 48,58 dan kelas kontrol berada dalam kategori rendah dengan nilai $\mathrm{N}$-Gain sebesar 22,34. Hasil pengujian hipotesis diperoleh nilai $t_{\text {hitung }}=28,34$ dan $t_{\text {tabel }}$ $=1,68$. Ini berarti bahwa nilai $t_{\text {hitung }}$ berada di luar daerah penerimaan $\mathrm{H}_{0}$. Dengan demikian dapat disimpulkan bahwa, ada pengaruh metode pembelajaran Whole Brain Teaching terhadap hasil belajar IPA siswa kelas VIII di SMP Negeri 18 Palu.
\end{abstract}

Kata Kunci :Whole Brain Teaching; Hasil belajar IPA

\section{PENDAhUlUAN}

Terdapat dua kendala dalam peningkatan kualitas pendidikan yaitu siswa yang kurang aktif dalam pembelajaran dan guru yang masih kurang efektif dalam mengajar ${ }^{[1]}$.Salah satu cara untuk mengatasi kendala tersebut adalah dengan memperbaiki sistem mengajar yang dilakukan oleh guru. Guru merupakan sumber utama pembelajaran yang memegang peranan penting dalam setiap pembelajaran ${ }^{[2]}$. Siswa yang cerdas dan dapat bersaing di dunia internasional bergantung pada guru yang memberikan pembelajaran di dalam kelas. Sehingga guru menjadi inti dari pembelajaran yang berlangsung.

Berdasarkan hasil observasi yang dilakukan di SMP Negeri 18 Palu, ditemukan bahwa ketika guru mengajar di depan kelas, siswa juga sibuk dengan aktivitasnya masingmasing. Hal ini disebabkan Karena kurangnnya perhatian guru terhadap siswa. Guru hanya memberikan materi tetapi tidak memperhatikan apakah siswa yang diajar mengerti tentang materi yang diberikan atau tidak. Sehingga diperlukan perhatian lebih dari guru, agar siswa dapat paham pada pembelajaran yang berlangsung. Kurang

aktifnya siswa dalam pembelajaran ini, diakibatkan guru yang memberikan pembelajaran kurang menyenangkan sehingga siswa sibuk sendiri dengan urusannya, hal ini berdampak pada hasil belajar siswa.

Hasil belajar adalah kemampuankemampuan yang dimiliki siswa setelah mengalami pengalaman belajarnya ${ }^{[3]}$. Dari pendapat tersebut dapat diketahui bahwa setiap kali siswa melakukan pembelajaran maka pada akhirnya siswa tersebut mengalami perubahan sebagai akibat dari pembelajaran yang dialaminya. Perubahan yang dialami siswa tersebutlah yang disebut dengan hasil belajar. Perubahan yang terjadi dalam diri seseorang banyak sekali baik sifat maupun jenisnya karena itu sudah tentu tidak setiap perubahan dalam diri seseorang merupakan pengertian dalam arti belajar ${ }^{[2]}$.

Hasil belajar juga merupakan hal yang sangat penting dalam proses belajar mengajar, karena dari sinilah dapat diketahui apakah proses pembelajaran berhasil atau tidak. Hasil belajar pula sangat berdampak 
pada prestasi yang di hasilkan oleh siswa. Semakin baik hasil belajar siswa maka prestasi yang dihasilkan siswa semakin baik pula begitupun sebaliknya. Salah satu faktor yang menyebabkan kurang baiknya hasil belajar siswa adalah metode pembelajaran yang digunakan guru masih kurang baik, sehingga pentingnya diterapkan metode pembelajaran yang dapat menarik perhatian siswa dalam belajar.

Metode pembelajaran adalah cara yang dipergunakan guru dalam mengadakan hubungan dengan siswa pada saat berlangsung pengajaran ${ }^{[3]}$. Dari penjelasan tersebut dapat diketahui bahwa betapa pentingnya metode pembelajaran, karena menjadi tonggak interaksi antara guru dan siswa. semakin efektif metode yang digunakan didalam kelas maka semakin efektif pula proses belajar mengajar yang berlangsung. Metode yang dapat digunakan agar dapat membuat siswa menjadi aktif dalam pembelajaran yaitu metode pembelajaran Whole Brain Teaching.

Metode pembelajaran Whole Brain Teaching merupakan metode yang menekankan penguasaan dan ketuntasan pemahaman serta kemampuan siswa untuk mengungkapkan kembali konsep, penjelasan ataupun rumus yang disampaikan oleh guru. Konsep dasar pembelajaran ini yaitu metode pembelajaran yang mengajarkan untuk mengenali prinsip belajar siswa yang dibagi menjadi tiga bagian yaitu visual, verbal dan body/kinestetik.Seperti dijelaskan oleh salah satu penciptanya yaitu Chris Biffle bahwa metode pembelajaran ini melibatkan para siswa dalam melihat, mendengar, melakukan, berbicara, dan merasa sementara mereka memiliki banyak bersenang-senang ${ }^{[4]}$. Dari penjelasan tersebut dapat diketahui bahwa siswa yang diajarkan dengan menggunakan metode pembelajaran ini dapat terlibat aktif dalam pembelajaran, dan siswa tidak akan merasa bosan. Strategi inti dalam menggunakan metode pembelajaran ini yaitu bagaimana cara untuk menarik perhatian siswa agar dapat lebih fokus pada pembelajaran yang sedang berlangsung ${ }^{[5]}$.

Metode ini memiliki 6 langkah pembelajaran yang sangat sederhana dan mudah dipahami yaitu class-yess, micro lecture, teach okey, score board, hand and eyes, dan comprehensions cheks ${ }^{[4]}$. Sedangkan pada pembelajaran dengan menggunakan metode pembelajaran ceramah siswa hanya disuguhkan materi tanpa harus terlibat aktif didalamnya.

Berdasarkan uraian di atas, maka peneliti melakukan penelitian dengan menggunakan metode pembelajaran Whole Brain Teaching terhadap hasl belajar IPA siswa kelas VIII di SMP Negeri 18 Palu.

\section{METODE PENELITIAN}

\section{1) Jenis dan Desain Penelitian}

Penelitian ini menggunakan metode eksperimen kuasi, dengan desain penelitian yang digunakan adalah "The Equivalen Pretest-Posttest Design" yaitu menggunakan kelas-kelas yang sudah ada sebagai kelompoknya, dengan memilih kelas-kelas yang diperkirakan sama keadaan/kondisinya. Bentuk desainnya disajikan pada Tabel 1.

Tabel 1. Desain Penelitian ${ }^{[6]}$

\begin{tabular}{lccc}
\hline Kelas & $\begin{array}{c}\text { Tes } \\
\text { Awal }\end{array}$ & $\begin{array}{c}\text { Variabel } \\
\text { terikat }\end{array}$ & $\begin{array}{c}\text { Tes } \\
\text { Akhir }\end{array}$ \\
\hline Eksperimen & $\mathrm{O}$ & $\mathrm{X}$ & $\mathrm{O}^{\prime}$ \\
Kontrol & $\mathrm{O}$ & - & $\mathrm{O}^{\prime}$ \\
\hline
\end{tabular}

Keterangan :

$X \quad$ :Metode pembelajaran Whole Brain Teaching

O :Tes awal

$\mathrm{O}^{\prime} \quad$ :Tes akhir

Pemilihan sampel pada penelitian ini menggunakan teknik Random sampling dengan cara menggulung kertas yang berisikan kelas yang akan dijadikan sampel kemudian peneliti bersama dengan guru disekolah tersebut memilih kelas yang akan dijadikan sampel penelitian. Dari pengambilan sampel maka terpilih kelas VIII $_{B}$ sebagai kelas eksperimen dan kelas VIII $_{A}$ sebagai kelas kontrol.

\section{2) Tempat dan Waktu Penelitian}

Penelitian ini dilaksanakan di SMP Negeri 18 Palu. Penelitian dilaksanakan pada tanggal 30 April - 13 Mei 2015.

\section{3) Teknik Analisis Instrumen}

Teknik analisis instrumen dilakukan sebanyak dua kali. Yang pertama, validitas ahli untuk mellihat isi dari soal tes yang akan digunakan. Yang kedua, menggunakan 
ISSN 23383240

validitas item, indeks kesukaran, daya pembeda, dan reliabilitas tes.

4) Teknik Analisis Data Hasil Penelitian

Teknik analisis data menggunakan uji normalitas, uji homogenitas, uji N-Gain, dan uji hipotesis.

\section{HASIL DAN PEMBAHASAN}

\section{1) Analisis Instrumen}

Instrumen yang digunakan dalam penelitian ini adalah tes hasil belajar IPA. Proses analisis tes dilakukan sebanyak dua kali. Yang pertama yaitu validitas ahli. Yang kedua yaitu uji coba tes.

Pada validasi ahli, dari 39 soal terpilih 30 soal yang diuji berdasarkan isi dari soal tersebut. Sedangkan pada validitas item yang diuji cobakan pada siswa kelas IX SMP Negeri 18 Palu. Kemudian dilakukan berbagai analisis instrumen yaitu berupa uji validitas item, indeks kesukaran, dan daya pembeda. Dari hasil analisis tersebut dari 30 soal ada 11 soal yang memenuhi syarat, 10 soal yang tidak dipakai (dibuang), dan 9 soal yang direvisi. Sehingga terdapat 20 soal yang dapat digunakan pada penelitian ini. Banyaknya soal yang tidak dapat dipakai disebabkan karena siswa yang diiuji cobakan sudah lupa pada materi pada soal tersebut. Kebanyakan dari mereka merasa bahwa soal tersebut sulit untuk dikerjakan karena materi pada soal telah lama dipelajari sebelumnya.

\section{2) Analisis Data Penelitian}

Penelitian ini menggunakan uji normalitas, Uji homogenitas, uji N-Gain, dan uji hipotesis. Uji normalitas bertujuan untuk melihat apakah data kedua kelas berdistribusi normal atau tidak. Uji homogenitas bertujuan untuk melihat data kedua kelas bersifat homogen atau tidak. Uji N-Gain bertujuan untuk melihat perbedaan peningkatan hasil belajar siswa baik dikelas kontrol maupun dikelas kontrol. Dan untuk Uji hipotesis digunakan untuk melihat pengaruh hasil belajar IPA siswa. Syarat untuk melakukan uji hipotesis data harus normal dan homogen. Jika data menunjukkan bahwa data tidak berdistribusi normal dan homogen maka uji hipotesis menggunakan uji statistik nonparametrik.

Tabel 2. Hasil penelitian kelas eksperimen dan kelas kontrol.

\begin{tabular}{c|cc} 
uraian & Tes awal & Tes akhir
\end{tabular}

\begin{tabular}{l|ccrc}
\hline & $\begin{array}{l}\text { Kelas } \\
\text { eksp. }\end{array}$ & $\begin{array}{l}\text { Kelas } \\
\text { kont. }\end{array}$ & $\begin{array}{r}\text { Kelas } \\
\text { eksp. }\end{array}$ & $\begin{array}{c}\text { Kelas } \\
\text { kont. }\end{array}$ \\
\hline $\begin{array}{l}\text { Rata-rata } \\
\text { Simpangan } \\
\text { baku }\end{array}$ & 6,78 & 6,15 & 13,31 & 9,26 \\
2,43 & 2,77 & 1,88 & 2,25 \\
\hline
\end{tabular}

Berdasarkan tabel 2 dapat dilihat bahwa pada saat melakukan tes awal skor rata-rata kelas eksperimen dan kelas kontrol tidak berbeda jauh, ini membuktikan bahwa kemampuan antara kedua kelas tersebut kurang lebih sama. Setelah diberikan perlakuan yang berbeda pada kedua kelas tersebut yaitu pada kelas eksperimen meggunakan metode pembelajaran Whole Brain Teaching skor rata-rata tes akhirnya lebih tinggi dibandingkan dengan kelas kontrol yang mengggunakan metode ceramah.

Dapat dikatakan bahwa metode pembelajaran Whole Brain Teaching dapat berpengaruh terhadap hasil belajar IPA siswa, hal ini disebabkan karena siswa dapat terlibat aktif dalam pembelajaran dengan mengikuti prinsip belajar siswa masing-masing yang tentunya berbeda-beda. Siswa yang tadinya pasif dalam pembelajaran dengan menerapkan metode pembelajaran ini siswa menjadi bersemangat dan lebiih fokus pada pembelajaran yang berlangsung. Sedangkan perolehan skor pada kelas yang diberikan metode pembelajaran ceramah lebih rendah. Hal ini disebabkan karena proses belajar mengajar lebih monoton. Siswa lebih cenderung pasif karena hanya menerima sajian materi dari guru.

Dari data tes hasil belajar tersebut, pertama-tama dilakukan uji normalitas untuk melihat apakah data tes tersebut terdistribusi normal. Pengujian dengan menggunakan uji normalitas ini menggunakan Chi-kuadrat dengan kriteria penerimaan $X^{2}$ Hitung $<X_{\text {tabel, }}^{2}$ taraf signifikan $a=0,05$, dan derajat kebebasan $\mathrm{dk}=\mathrm{k}-3$. Data yang digunakan untuk menguji normalitas meliputi tes awal (pretest) hasil belajar dan tes akhir (postest) hasil belajar baik dikelas eksperimen maupun dikelas kontrol. Diperoleh hasil pengujian normalitas tes awal dan tes akhir pada kedua kelas dapat dilihat pada tabel 3.

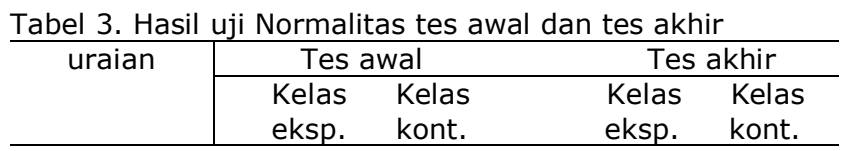




\begin{tabular}{l|cccc}
\hline sampel & 19 & 19 & 19 & 19 \\
$X^{2}{ }_{\text {hitung }}$ & 5,48 & 1,50 & 5,08 & 4,26 \\
$X^{2}$ tabel & 5,99 & 5,99 & 5,99 & 5,99 \\
keterangan & \multicolumn{2}{|c}{ Normal } & \multicolumn{2}{c}{ Normal } \\
\hline
\end{tabular}

Berdasarkan uji normalitas pada Tabel 3 dengan menggunakan Chi-kuadrat dengan kriteria penerimaan $X^{2}$ hitung $<X_{\text {tabel, dimana }}^{2}$ untuk tes awal baik kelas eksperimen maupun kelas kontrol nilai $X^{2}$ hitung lebih kecil daripada nilai $X^{2}$ tabel. Begitupun untuk tes akhir, nilai $X^{2}$ hitung lebih kecil daripada nilai $X^{2}$ tabel baik kelas eksperimen dan kelas kontrol. sehingga dapat dikatakan bahwa data yang diperoleh pada penelitian ini berdistribusi normal.

Selain uji normalitas, dilakukan pula uji homogenitas. Dari uji homogenitas diperoleh nilai $F_{\text {hitung }}=1,14$ dan $F_{\text {tabel }}=2,15$. Syarat bahwa data bersifat homogen adalah $\mathrm{F}_{\text {hitung }}<$ $F_{\text {tabel. }}$ Dapat disimpulkan bahwa kelas eksperimen dan kelas kontrol bersifat homogen.

Berdasarkan hasil penelitian yang diperoleh, untuk melihat peningkatan hasil belajar maka dilakukan uji $\mathrm{N}$-gain pada kelas kesperimen dan kelas kontrol seperti pada Tabel 4.

Tabel 4. Uji N-Gain Kelas Eksperimen Dan Kelas Kontrol

\begin{tabular}{lcc}
\hline Uraian & Kelas eksperimen & Kelas kontrol \\
\hline Sampel & 19 & 19 \\
Nilai Terendah & 38,56 & 0 \\
Nilai Tertinggi & 86,67 & 33,33 \\
N-Gain & 48,58 & 22,54 \\
\hline
\end{tabular}

Dari tabel 4 dapat dilihat adanya perbedaan peningkatan hasil belajar IPA siswa antara kelas eksperimen dan kelas kontrol. Dimana kelas eksperimen terjadi peningkatan yang lebih baik dibandingkan dengan kelas kontrol yaitu dengan nilai N-Gain 48,58.

Berdasarkan hasil yang diperoleh dari uji $\mathrm{N}$-Gain, diketahui bahwa terjadi peningkatan hasil belajar pada kelas eksperimen dibandingkan kelas kontrol. Hal ini dipengaruhi oleh siswa yang turut aktif dalam pembelajaran. Dengan terlibat aktifnya siswa dalam pembelajaran tentunya akan berdampak positif terhadap hasil belajar siswa dan siswa juga akan lebih mudah memahami materi yang diberikan oleh guru, karena disini siswa dituntut untuk mengungkapkan kembali materi tersebut dengan menggunakan bahasa-bahasa tubuh sesuai dengan prinsip dasar belajar siswa itu sendiri.

Setelah melakukan uji normalitas, uji homogenitas, uji N-Gain, maka selanjutnya dilakukan uji hipotesis untuk melihat ada tidaknya pengaruh hasil belajar IPA dari kedua kelas tersebut. Dari hasil uji hipotesis kelas eskperimen dan kelas kontrol menunjukkan $t_{\text {hitung }}=28,34$ dan $t_{\text {tabel }}=1,68$ atau $t_{\text {hitung }}>$ $t_{\text {tabel}}$. Hal ini berarti, nilai $t_{\text {hitung }}$ berada diluar daerah penerimaan $\mathrm{H}_{0}$. Dengan demikian $\mathrm{H}_{0}$ ditolak dan $\mathrm{H}_{1}$ diterima.

Setelah dilakukan analisis hipotesis diketahui bahwa setelah diberikan metode pembelajaran Whole Brain Teaching menunjukkan ada pengaruh hasil belajar IPA pada kelas yang diberikan metode pembelajaran Whole Brain Teaching, Karena pada pembelajaran dengan menggunakan metode ini siswa dituntut untuk mengungkapkan kembali konsep, penjelasan ataupun rumus yang disampaikan oleh guru dengan gerakan-gerakan yang menarik. Siswa yang awalnya masih terlihat malu untuk mengungkapkan kembali materi yang diberikan dengan gerakan-gerakan yang menarik terlihat bersemangat dapat melakukan gerakan tersebut dengan baik seperti mereka sedang bermain bersama dengan teman-temannya.

Ciri khas dari metode pembelajaran Whole Brain Teaching adalah guru hanya mengajarkan materi selama 30 detik dengan diikuti gerakan-gearakan yang menarik kemudian siswa mengungkapkan kembali materi tersebut dengan teman sebangkunya dengan megikuti gerakan-gerakan yang dilakukan oleh guru. Cara ini dapat meningkatkan keaktifan siswa dalam pembelajaran dan dapat mengenali prinsip belajar siswa itu sendiri yang terdiri dari tiga bagian yaitu Visual, verbal dan body/kinestetik. Metode ini juga dapat meningkatkan semangat belajar siswa dengan adanya sapaan antara guru dan siswa yaitu class-yess. Metode ini juga menggunakan penilaian langsung yang diberikan oleh guru terhadap kinerja siswa selam proses belajar mengajar berlangsung, penilaian ini dituliskan pada score board. Dan guru dapat memberikan sanksi sesuai kesepakatan diawal pembelajaran berdasarkan penilaian yang terlihat pada score board. 
Dari penelitian terdahulu, menyatakan bahwa pendekatan Accelerated learning dengan metode pembelajaran Whole Brain Teaching ini mampu meningkatkan hasil belajar siswa karena pada pembelajaran dengan menggunakan Whole Brain Teaching siswa tidak hanya sekedar mendengar dan memperhatikan penjelasan dari guru tetapi menghendaki aktivitas siswa dalam proses berfikir dan beberapa gerakan tubuh ${ }^{[1]}$. Tujuan dari strategi ini adalah siswa bukan sekedar menguasai materi tetapi bagaimana mengembangkan gagasan dan ide melalui bahasa tubuh. Sedangkan pada pembelajaran dengan menggunakan metode ceramah siswa hanya disuguhkan materi tanpa harus terlibat aktif didalamnya. Penggunaan metode Whole Brain Teaching berpengaruh signifikan terhadap aktivitas belajar siswa, hal ini disebakan karena siswa yang tadinya pasif dan hanya menonton saja saat proses belajar mengajar didalam kelas menjadi aktif sehingga aktivitas belajarnya meningkat ${ }^{[7]}$.

Hasil yang didapat pada penelitian ini dibandingkan dengan penelitian terdahulu yaitu pada penelitian ini peneliti hanya menggunakan metode pembelajaran Whole Brain Teaching, tanpa menggabungkan dengan pendekatan yang lain. Hal ini menyebabkan penelitian ini hanya terfokus pada metode pembelajaran Whole Brain Teaching. Selain itu yang membedakan penelitian ini dari penelitian sebelumnya yaitu penelitian ini menggunakan materi alat-alat optik pada SMP.

\section{KESIMPULAN DAN SARAN}

Berdasarkan hasil penelitian dan analisis data yang diperoleh, maka dapat disimpulkan bahwa metode pembelajaran Whole Brain Teaching dapat mempengaruhi hasil belajar IPA siswa kelas VIII SMP Negeri 18 Palu. Hal ini dapat dilihat dari hasil pengujian statistik, $t_{\text {hitung }}>t_{\text {tabel }}$ atau 28,43 $>1,68$ atau $\mathrm{H}_{0}$ ditolak dan $\mathrm{H}_{1}$ diterima.

Adapun saran dalam penelitian ini yaitu Peneliti mengharapkan adanya penelitian lain yang menggunakan matode Whole Brain Teaching dengan materi yang berbeda dan karakteritik yang berbeda sehingga dapat digunakan sebagai bahan pertimbangan dalam penerapannya disekolah.

\section{DAFTAR PUSTAKA}

[1] Albab, A.F. dan Astutik, S. (2012). "Penerapan Pendekatan Accelerated Learning Dengan Metode Whole Brain Teaching Dalam Pembelajaran Fisika SMP". Jurnal pembelajaran fisika FKIP Universitas jember. Vol.1, no. 1, 1-5. [online] Tersedia:http://repository.unej.ac.

id/bitstream/handle/123456789/429/ html. [12 november 2014]

[2] Slameto. (2010). Belajar dan Faktor-Faktor yang Mempengaruhinya. Jakarta: Rineka Cipta.

[3] Sudjana. (2007), Penelitian dan Penilaian Pendidikan. Bandung: Sinar Baru Algensido Offset.

[4] Szott, M. dan Molitoris, M. (2010). How can Whole Brain Teaching impact our Classroom environment? [online]. Tersedia: http: //www. ed. psu. edu/pds/teacher-inquiry /2010 /szottMaria_molitorisMegan _ 20092010 Inquiry. Pdf. [15 november 2014].

[5] Biffle, C. 2010. Whole Brain Teaching for Challenging Kids. [online]. Tersedia: http://www. wholebrainteaching.com/licenseresult/32 -whole-brain-teaching-for- challengingkids.html?bid=32.html [12 november 2014].

[6] Sugiyono. (2010) .Metode Penelitian Pendidikan (Pendekatan Kuantitatif, Kualitatif dan R\&D). Bandung: Alfabeta

[7] Stiyowati, R. (2012). Pengaruh metode Whole Brain Teaching terhadap aktivitas dan hasil belajar siswa kelas XI SMA 1 Jember. Skripsi Universitas Jember: [online]. Tersedia: http:// repository. unej. ac. id/ handle/ 123456789/ 10532? show=full. Pdf. [15 november 2014]. 